\title{
Expression of interleukin 1, interleukin 6 and tumour necrosis factor $\alpha$ in mouse uterus during the peri-implantation period of pregnancy
}

\author{
M. De, T. R. Sanford and G. W. Wood \\ Department of Pathology and Oncology, University of Kansas Medical Center, 39th and Rainbow \\ Boulevard, Kansas City, KS 66103, USA
}

\begin{abstract}
Interleukin 1 (IL-1), IL- 6 and tumour necrosis factor alpha (TNF- $\alpha$ ) are expressed in the mouse uterus on days $1-3$ of pregnancy. Cytokine production is temporally associated with the post-mating intrauterine acute inflammatory response. In this study, IL-1, IL- 6 and TNF- $\alpha$ were detected in the uterus of pregnant mice from day 3 to day 9, using northern blotting, bioassays and immunocytochemistry. IL-1 bioactivity increased from a low concentration on day 3 to a peak between days 4 and 5 and decreased to low concentrations on days 7 and 8 . Blastocyst implantation occurs late on day 4. IL-6 bioactivity was high from day 3 to day 9 and activity was maximal on days 5 and 6 . TNF- $\alpha$ bioactivity increased from its lowest concentration on day 3 to a peak on day 8 . Although changes in bioactivity concentrations occurred at different times from changes in mRNA concentrations, the changes were approximately parallel. Translation of mRNA into an immunologically detectable product was confirmed using immunocytochemistry with polyclonal anti-cytokine antibodies. We conclude that the cytokines IL-I, IL- 6 and TNF- $\alpha$ are produced in the uterus during the periimplantation period of pregnancy in mice. Changes in cytokine concentrations suggested the existence of some form of regulated expression.
\end{abstract}

\section{Introduction}

Successful implantation and continued development of implanted embryos depend on a complex series of cellular and molecular changes induced in the preimplantation uterus by oestrogen and progesterone (Shelesnyak, 1955; Psychoyos, 1973; Short, 1984). Several recent findings suggest that some hormone-dependent changes may be due to local actions of polypeptide growth factors, such as epidermal growth factor and insulin-like growth factor 1 (DiAugustine et al., 1988; Murphy et al., 1988; Brigstock et al., 1989; Croze et al., 1990; Huet-Hudson et al., 1990; Nelson et al., 1991). These and related factors may function as autocrine or paracrine regulators of uterine cell proliferation and differentiation. The pro-inflammatory cytokines IL-1, IL- 6 and TNF- $\alpha$ constitute another group of locally acting polypeptide growth factors, which are powerful stimulators of cell proliferation, differentiation and programmed cell death (Billingham, 1987; Balkwill and Burke, 1989; Dinarello, 1989; Durum and Oppenheim, 1989). IL-1, IL-6 and TNF- $\alpha$ and factors that they secondarily induce, such as prostaglandins, leukotrienes, histamine and other cytokines, are mediators of host inflammatory responses to pathogenic stimuli and are essential cofactors in immune responses (Billingham, 1987; Balkwill and Burke, 1989; Dinarello, 1989; Durum and Oppenheim, 1989). Until recently, studies of cytokine expression and function were limited to pathological conditions, e.g. responses to endotoxin.

In situ hybridization showed IL-1 $\alpha$ and IL-1 $\beta$ mRNA transcripts in the endometrium of the uterus of nonpregnant

Received 7 January 1992. mice, whereas IL- 1 expression would not be detected in other normal tissues, suggesting that, during the oestrous cycle, IL-1 production was higher in the uterus than in other organs (Takacs et al., 1988). High concentrations of IL-1, IL- 6 and TNF- $\alpha$ were detected in the mouse uterus on days 1 and 2 of pregnancy (Sanford et al., 1992). Cytokine production accompanied the post-mating intrauterine acute inflammatory response (Lobel et al., 1967; De et al., 1991). To determine whether cytokines are also expressed in the uterus during the peri-implantation period of pregnancy, we determined IL-1, IL- 6 and TNF- $\alpha$ gene transcription and translation by northern blotting of uterine mRNA, by specific cytokine bioassay of soluble uterine extracts and by immunocytochemical analysis of uterine cells with cytokine-specific antibodies on days 3-9 of pregnancy.

\section{Materials and Methods}

\section{Animals}

Swiss CD1 mice (7-8 weeks old) were purchased from Harlan/Sprague Dawley, (Indianapolis, IN) and maintained and bred in the University of Kansas Animal Care Facility. One male was combined with two females, and the females were observed for the formation of a vaginal plug so that the time of onset of pregnancy could be recorded. The day of plug appearance was designated as day 1 of pregnancy. BALB/c mice ( $4-6$ weeks old) were obtained from Harlan/Sprague Dawley for use in IL-1 bioassays. 


\section{Detection and measurement of messenger RNA}

Mice were killed by asphyxiation with $\mathrm{CO}_{2}$ and the uterus and liver were removed, pooled and snap-frozen in liquid $\mathrm{N}_{2}$. Frozen tissue from ten mice for uterus and four mice for liver was homogenized using a polytron, and total RNA was isolated from tissue by the guanidine isothiocyanate method (Han et al., 1987). RNA was isolated from two groups of mice. Poly(A) RNA was isolated from total RNA from one of the groups by adsorption to and elution from oligo (dt) cellulose (type 3 ) (Aviv and Leder, 1972). The mRNA yield from the poly(A) columns was uniform, ranging from 2 to $3 \%$ of the total RNA in each sample. cDNA clones for murine IL- $1 \alpha$ (Lomedico et al., 1984), IL-1 $\beta$ (Huang et al., 1988), IL- 6 and TNF- $\alpha$ were obtained and subcloned into pSP6 or pGEM vectors (Promega Biotech, Inc., Madison, WI). Anti-sense IL-I $\alpha$, IL-1 $\beta$, IL- 6 and TNF- $\alpha$ riboprobes were synthesized using $\left[{ }^{32} \mathrm{P}\right] \mathrm{GTP}\left(>600 \mathrm{Ci} \mathrm{mmol}^{-1}\right)$ and had specific activities between 2 and $4 \times 10^{8}$ d.p.m. $\mathrm{mg}^{-1}$ (Melton et al., 1984). RNA in individual samples was measured by UV absorbance at $260 \mathrm{~nm}$. Cytokine-specific mRNA was localized in all samples by northern blotting (Andrews et al., 1987). The positive control for all of the cytokine probes was total RNA obtained from J774 cells stimulated with lipopolysaccharide from Escherichia coli. J774 is a macrophage cell line, which was obtained from the American Type Culture Collection (Bethesda, MD). Lipopolysaccharide stimulation was performed by growing J774 cells in suspension, exposing growing cells $\left(10^{6}\right.$ cells $\mathrm{ml}^{-1}$ ) to lipopolysaccharide ( $100 \mathrm{ng} \mathrm{ml}^{-1}$ ) for $3 \mathrm{~h}$ and collecting cells by sedimentation. RNA was extracted from a total of $5 \times 10^{8}$ cells by the phenol-chloroform method. The density of bands was determined by scanning densitometry. Peak areas were measured by laser densitometry using a Biomed 1D/2D Laser Densitometer (Biomed Instruments, Fullerton, CA). Band areas are reported in arbitrary units.

\section{Cytokine measurement}

Mice were killed by asphyxiation with $\mathrm{CO}_{2}$. Uteri were immediately removed and snap-frozen in liquid $\mathrm{N}_{2}$. Uteri from five mice were pooled, homogenized in RPMI 1640 using a Dounce homogenizer and sedimented at $27000 \mathrm{~g}$ for $10 \mathrm{~min}$. The supernatant was removed and sterilized by filtration. Supernatants were prepared from two groups of mice. The protein concentration of the supernatants was determined by measuring absorbance at $595 \mathrm{~nm}$. The supernatants were analysed for cytokine activity using bioassays.

IL-I was determined by a modification of the standard thymocyte proliferation stimulation assay (Wood et al., 1988). IL-I was measured by its ability to augment thymocyte proliferation in the absence of exogenous mitogens. Specificity was determined by inhibition of activity with polyclonal antimouse IL-1 (Genzyme Corp., Cambridge, MA). Recombinant human IL-I $\alpha$ (Immunex Corp., Seattle, WA) served as the positive control. Each sample was assayed in quadruplicate. Assays were performed twice on each sample from both groups to demonstrate reproducibility.

IL- 6 was assayed using the B9 cell line that is dependent on IL-6 (Lemay et al., 1990). Samples were assayed in triplicate and the assays were repeated with nearly identical results. Standard curves were prepared using recombinant human IL-6, and IL-6 values for test samples were derived from the curves and expressed as units. Data are expressed as units $\mu \mathrm{g}^{-1}$ protein. Assays were performed on a single set of supernatants derived from a pool of five mice per day. Statistical analysis was not applied to the data.

TNF- $\alpha$ was assayed by the standard L929 cytotoxicity method (Mosmann, 1983). Specificity was determined by inhibition of activity with polyclonal anti-mouse TNF- $\alpha$ (Genzyme Corp.). Standard curves were prepared using recombinant human TNF- $\alpha$, and TNF- $\alpha$ values for test samples were derived from the curves and expressed as units. The protein concentration of test samples was determined, and data are expressed as units $\mathrm{mg}^{-1}$ protein. Each sample was assayed in triplicate. Assays were performed twice on each sample from both groups.

\section{Immunocytochemistry}

Mice were killed by asphyxiation with $\mathrm{CO}_{2}$. Uteri were immediately removed and cell suspensions prepared by enzyme digestion. Uteri from four mice were pooled for each day of pregnancy. Cell suspensions of uterine tissue were prepared by digestion at ambient temperature for $60 \mathrm{~min}$ with type I collagenase ( $1 \mathrm{mg} \mathrm{ml}^{-1}$, Worthington Biochemical, Malverne, PA) and type XV protease from Bacillus polymyxa $\left(5 \mathrm{mg} \mathrm{ml}^{-1}\right.$, Sigma, St Louis, MO). The dispersed cells were washed with RPMI 1640 containing $5 \%$ fetal bovine serum and cytocentrifuged directly onto slides. The cells were vacuum dried, fixed in periodate-lysine-paraformaldehyde buffer for $10 \mathrm{~min}$ and immediately stained with anti-cytokine antibodies by the indirect immunoperoxidase method using Vectastain $\mathrm{ABC}$ kits (Vector Laboratories, Burlingame, CA). Polyclonal anti-IL-1 (Genzyme Corp, Cambridge, MA), IL-6 (R \& D Systems, Minneapolis, MN) and TNF- $\alpha$ (Genzyme Corp.) were all diluted 1:250 in all assays. The cells were counterstained with methyl green. Six slides were stained at each data point. Slides were then coded and scored in a double blind fashion. Intensity of staining was scored from negative to $5+$; grading was independently performed by two of the authors and results were internally consistent. The assay was performed twice on separate groups of animals. All data points for each group were generated in a single experiment performed on one day.

\section{Statistical analysis}

Statistical analysis of differences between cytokine concentrations on different days of pregnancy was done using the Newman-Keul's multiple-comparison test following the one-way analysis of variance (ANOVA for repeated measures) test using the IBM SAS computer program. The statistical analyses were performed on IL- 1 and TNF- $\alpha$ bioassay data generated by performing assays on samples obtained from two separate pools of mice from each day of pregnancy.

\section{Results}

\section{Expression of cytokine $m R N A$ in the uterus}

Messenger RNA for IL-1 $\alpha$ was not detected on day 3, but high concentrations were detected in samples obtained in the 
(a)

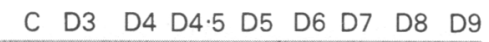

$2 \cdot 2 \mathrm{~kb}$

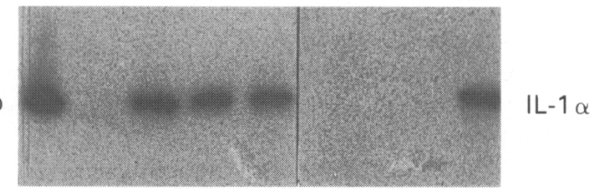

(b)

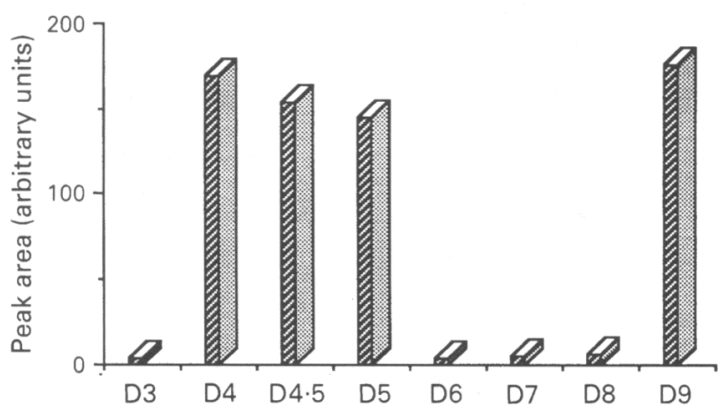

(c)

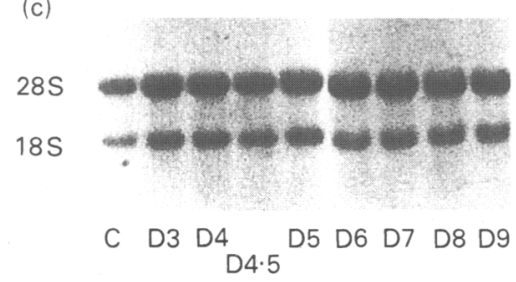

Fig. 1. Northern blot for mouse interleukin I $\alpha$ (IL-I $\alpha$ ). The control (C) lane contains $1.1 \mu \mathrm{g}$ of total RNA from lipopolysaccharide-stimulated J774 cells (macrophage cell line). Other lanes (D3-9) contain $2.2 \mu \mathrm{g}$ of uterine poly(A) RNA from mice killed on days 3-9 of pregnancy. (a) Northem blot, (b) spectrodensitometric analysis and (c) acridine-orangestained gel containing $1.1 \mu \mathrm{g}$ of control cell RNA (C) or $6.6 \mu \mathrm{g}$ of the uterine RNA from which the poly(A) RNA was prepared (D3-D9).

morning and afternoon of day 4 (Fig. 1). The concentration of IL- $1 \alpha$ mRNA remained high until day 5 , substantially decreased on day 6 and remained low until day 8 . An increase in the concentration of IL-I $\alpha$ mRNA was detected again on day 9 . IL- $1 \beta$ mRNA was not detected in the uterus on day 3 or on the morning of day 4 , but was detected in the afternoon of day 4 (Fig. 2). The concentration of IL-1 $\beta$ mRNA decreased progressively from day 5 to day 9 . IL-6 (Fig. 3) and TNF- $\alpha$ mRNA were detected in each sample from each day. The concentration of IL-6 mRNA increased progressively from its lowest point on day 3 to a high on day 6 , decreased until day 8 and then increased again on day 9. The concentration of TNF- $\alpha$ mRNA also increased from a low point on days 3 and 4 to a high on day 6 , then decreased until day 9 (Fig. 4).

The expression of cytokine mRNA in the uterus during pregnancy was demonstrated to be organ specific by blotting liver RNA from days 3-9 with probes of IL-1 $\alpha$, IL-1 $\beta$, IL- 6 and TNF- $\alpha$. No cytokine mRNA was detected in liver.

\section{Cytokine bioactivity in the uterus}

Northern blot analysis showed that IL-I, IL- 6 and TNF- $\alpha$ gene transcription occurred in the uterus during the peri- (a)
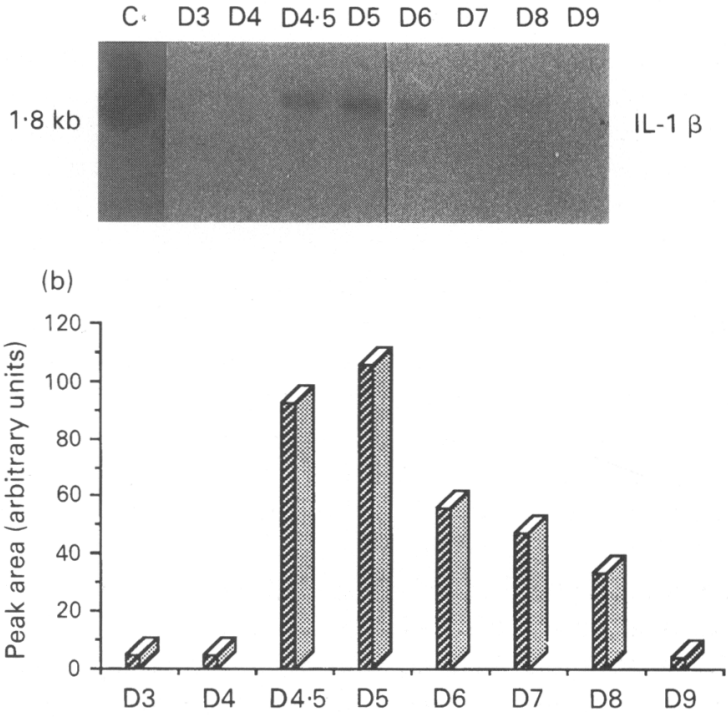

(c)

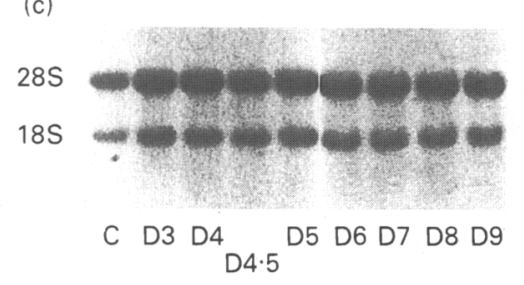

Fig. 2. Northern blot for mouse interleukin $1 \beta$ (IL-1 $\beta$ ). The control (C) lane contains $1.1 \mu \mathrm{g}$ of total RNA from lipopolysaccharide-stimulated J774 cells (macrophage cell line). Other lanes (D3-D9) contain $2.2 \mu \mathrm{g}$ of uterine poly (A) RNA from mice killed on days 3-9 of pregnancy. (a) Northern blot, (b) spectrodensitometric analysis and (c) acridineorange-stained gel containing 1.I $\mu \mathrm{g}$ of control cell RNA (C) or $6.6 \mu \mathrm{g}$ of the uterine RNA from which the poly(A) RNA was prepared (D3-D9).

implantation period of pregnancy. Cytokine-specific bioassays were performed on soluble extracts of uterine tissue to determine whether those messages were translated into biologically active cytokines and whether changes in concentrations of cytokine bioactivity occurred between days of pregnancy. A high concentration of IL-I bioactivity was already present in the tissue on day 3 (Fig. $5 \mathrm{a}$ ). The IL-I concentration increased to peak values on day 4 , and then decreased progressively to day 6. Tissue extracts were obtained from pregnant mice in the morning and afternoon of day 4. The concentration of bioactive IL- 1 in the two samples was nearly identical. The difference in activity between days 4 and 6 was statistically significant $(P<0.001)$. The IL-1 concentration increased progressively from day 6 to day 9 and the difference between the values obtained on days 6 and 9 was statistically significant $(P<0.001)$.

A high concentration of IL- 6 bioactivity was present in the tissue on day 3 , and the concentration increased to a peak on day 5 (Fig. 5b). After decreasing on days 6 and 7, the tissue IL- 6 concentration increased progressively until day 9 .

TNF- $\alpha$ bioactivity increased progressively to its highest concentration on day 8 and remained high until day 9 (Fig. 5c). The differences between the concentration detected on day 3 
(a)

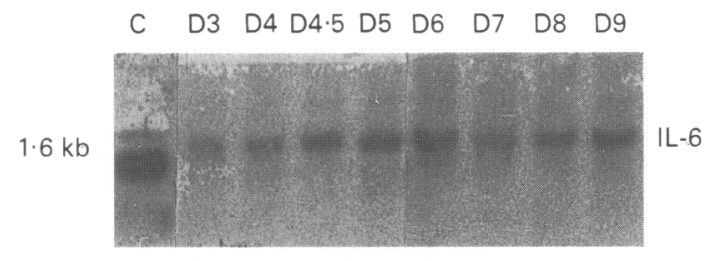

(b)

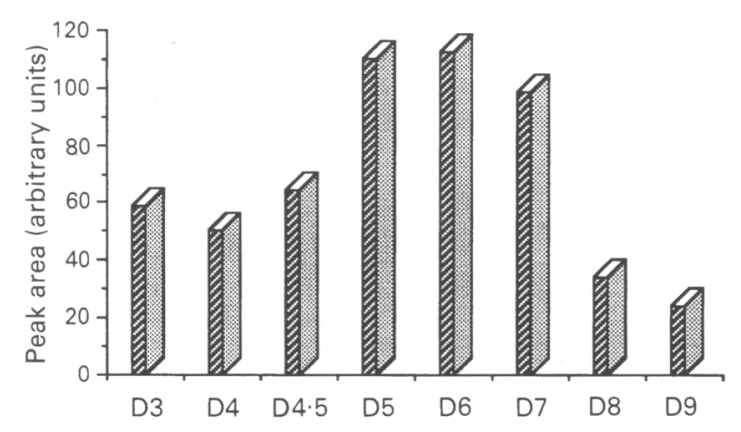

(c)

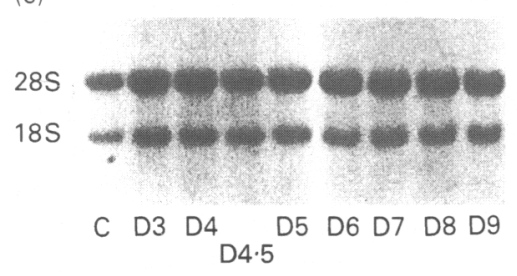

Fig. 3. Northern blat for mouse interleukin 6 (IL-6). The control (C) lane contains $1.1 \mu \mathrm{g}$ of total RNA from lipopolysaccharide-stimulated J774 cells (macrophage cell line). Other lanes (D3-D9) contain $2.2 \mu \mathrm{g}$ of uterine poly(A) RNA from mice killed on days 3-9 of pregnancy. (a) Northern blot, (b) spectrodensitometric analysis and (c) acridineorange-stained gel containing $1.1 \mu \mathrm{g}$ of control cell RNA (C) or $6.6 \mu \mathrm{g}$ of the uterine RNA from which the poly(A) RNA was prepared (D3-D9).

and concentrations detected on days $4-7$ were statistically significant $(P<0.001)$. The differences between the concentrations detected on days $3-7$ and the concentrations detected on days 8 and 9 were also statistically significant $(P<0.001)$.

\section{Immunocytochemical detection of IL-1, IL-6 and TNF- $a$ in uterine cells}

An independent analysis of cytokine gene products in uterine tissue was provided by identifying IL-1, IL- 6 and TNF- $\alpha$ in isolated uterine cells using cytokine-specific polyclonal antibodies. IL-1, IL- 6 and TNF- $\alpha$ were detected in uterine cells on each day tested (Table I). The IL-1 staining intensity varied substantially from day to day. Cells were strongly stained for IL- $I$ on day 4 and on days $7-9$, but only weakly stained on the other days (Fig. 6, Table 1). Cells were strongly positive for IL-6 and TNF- $\alpha$ on days $3-9$ (Fig. 6, Table 1).

The staining pattern for the different cytokines was noteworthy. Generally, there was little difference in the staining intensity between positive cells on a given slide, but cells exhibited different staining patterns. Slides stained with antiIL- 1 and anti-IL- 6 exhibited a pattern in which a few cells (a)
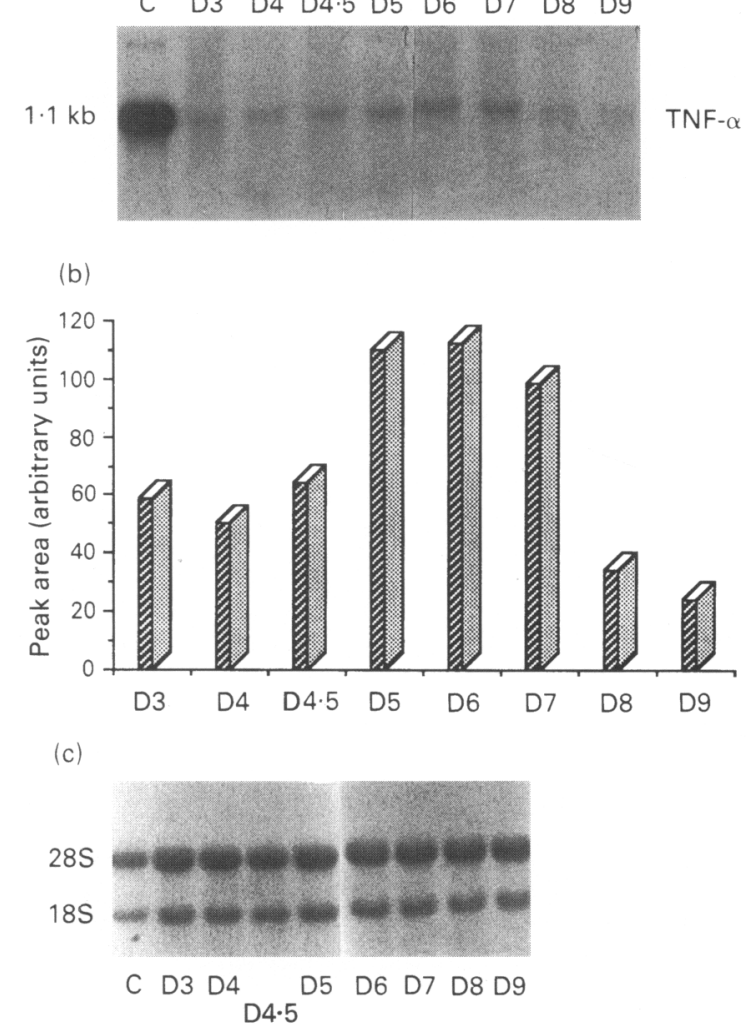

Fig. 4. Northern blot for mouse tumour necrosis factor alpha (TNF- $\alpha$ ). The control (C) lane contains $1.1 \mu \mathrm{g}$ of total RNA from lipopolysaccharide-stimulated J774 cells (macrophage cell line). Other lanes (D3-D9) contain $2.2 \mu \mathrm{g}$ of uterine poly(A) RNA from mice killed on days 3 to 9 of pregnancy. (a) Northern blot, (b) spectrodensitometric analysis and (c) acridine-orange-stained gel containing $1.1 \mu \mathrm{g}$ of control cell RNA (C) or $6.6 \mu \mathrm{g}$ of the uterine RNA from which the poly $(\mathrm{A})$ RNA was prepared (D3-D9).

were unstained, some cells were stained evenly throughout their cytoplasm and the majority of the cells exhibited strong peripheral staining (Fig. 6a-c). In contrast, in anti-TNF- $\alpha$ stained populations, a few cells were unstained, while the remainder were homogeneously stained (Fig. 6d).

\section{Controls}

All bioassays and northern blots were performed with a positive control. Northern blots were performed on poly(A) RNA to demonstrate that what was being detected was in the mRNA fraction. Similar data were obtained from total RNA samples obtained from a second group of mice from each day of pregnancy. All bioassay results were confirmed by total inhibition of activity with specific antibody. The immunocytochemistry was controlled by staining cells from each day of pregnancy with buffer alone and with normal rabbit serum.

\section{Discussion}

The present studies demonstrated expression of genes for IL-I, IL- 6 and TNF- $\alpha$ in the uterus during the peri-implantation 

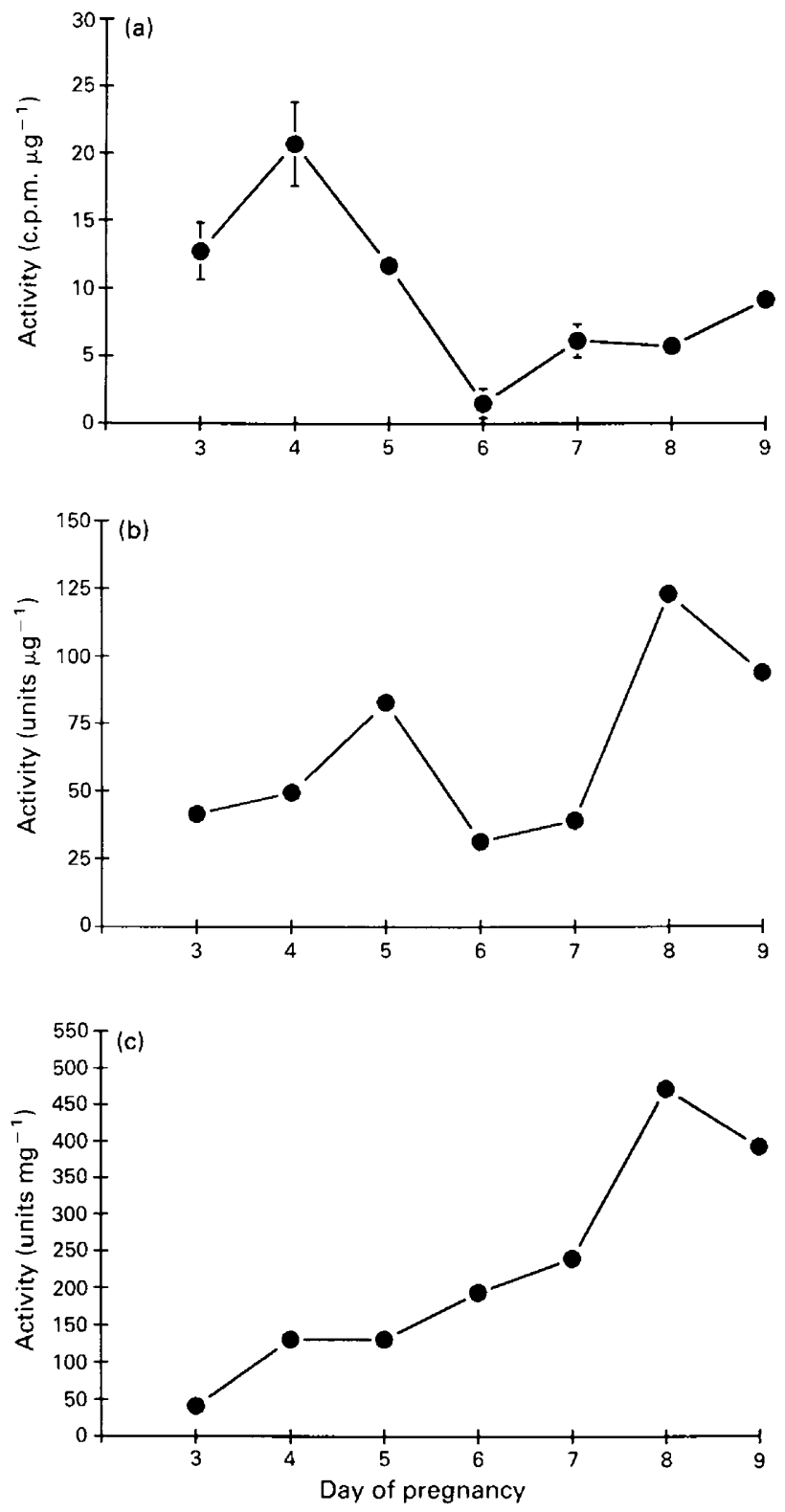

Fig. 5. Bioactivity of (a) interleukin 1, (b) interleukin 6 and (c) tumour necrosis factor $\alpha$ in uterine tissue from days 3-9 of pregnancy.

period of pregnancy in mice. That conclusion is based on direct analysis of tissue-associated cytokine by bioassay and immunocytochemistry and cytokine mRNA by northern blotting. The three methods used for cytokine measurement are based on different principles and the assays were performed independently on qualitatively different tissue samples. The data from each approach therefore provide internal verification of the data obtained using the others. Directly assaying tissue extracts avoids cell culture artefacts. The amount of cytokine detected should reflect a combination of cytokine production, use and breakdown occurring in the tissue during the period immediately preceding its collection.

The IL-1 concentration increased dramatically in the uterus immediately before implantation, which, in mice, occurs late
Table 1. Detection of cytokines in uterine cells of mouse using immunocytochemistry*

\begin{tabular}{lccccccc}
\hline & 3 & 4 & 5 & 6 & 7 & 8 & 9 \\
\hline $\begin{array}{l}\text { PBS/NRS } \\
\text { Interleukin 1 }\end{array}$ & $1+$ & $4+$ & $1+$ & $1+$ & $3+$ & $3+$ & $4+$ \\
$\begin{array}{l}\text { Interleukin 6 } \\
\text { Tumour necrosis } \\
\text { factor } \alpha\end{array}$ & $2+$ & $3+$ & $3+$ & $3+$ & $4+$ & $3+$ & $4+$ \\
\hline
\end{tabular}

${ }^{*}$ Dispersed uterine cells were cytocentrifuged onto slides, vacuum dried, fixed and stained with anti-cytokine antibodies, phosphate-buffered saline (PBS) or normal rabbit serum (NRS). Slides were coded, intensity of staining was scored double-blind from - to $5+$ and the scores were averaged. All slides were stained on the same day.

on day 4. The IL-1 increase was temporally associated with the previously reported preimplantation surge in oestrogen (Shelesnyak, 1955; Yoshinaga et al., 1969; Psychoyos, 1973; Short, 1984). It is unclear why there was a high concentration of IL- 1 in the uterus on day 3 when IL-I mRNA was undetectable. However, earlier studies demonstrated that high concentrations of IL-I $\alpha$ and IL-I $\beta$ mRNA and IL-1 bioactivity are present in the uterus on days 1 and 2 and that both mRNA and bioactivity decreased from day 1 to day 3 (Sanford et al., 1992). It is possible that the rate of degradation of mRNA was higher than that of bioactive product in the tissue. A dramatic decrease in IL-1 production also occurred during the post-implantation period. Changes in IL-1, IL- 6 and TNF- $\alpha$ concentrations occurred in a predictable order based on previous studies of cytokine induction by endotoxin. IL-1 $\alpha$ preceded IL-1 $\beta$, IL-1 $\beta$ preceded IL- 6 , and IL- 6 preceded TNF- $\alpha$ (Billingham, 1987; Balkwill and Burke, 1989; Dinarello, 1989; Durum and Oppenheim, 1989). The delayed expression of IL- 6 and TNF- $\alpha$ relative to IL- $\mathrm{I}$ was consistent with observations in other systems that IL- $I$ is an autocrine and paracrine inducer of IL- 6 and TNF- $\alpha$ (Billingham, 1987; Balkwill and Burke, 1989; Dinarello, 1989; Durum and Oppenheim, 1989).

The temporal association between IL-I production in the pregnant uterus and increased concentrations of ovarian hormones may be related to the ability of oestrogen and progesterone to induce IL- 1 synthesis in uterine cells. Other studies in this laboratory demonstrated that IL-1 and IL-I mRNA were undetectable in uteri from ovariectomized mice, but were rapidly induced by both oestrogen and progesterone (De $e t$ al., 1992). Delayed expression of IL- 6 and TNF- $\alpha$ in the uterus during pregnancy was also consistent with the observations made in ovariectomized mice. Significant amounts of IL-6 or TNF- $\alpha$ were produced only in the uterus following exposure of ovariectomized mice to a combination of oestrogen and progesterone (De et al., 1992).

The current study provided no insight into the cell source for any of the intrauterine cytokines. However, the findings may be related to previous reports that oestrogen induces IL-I production in cultured macrophages (Flynn, 1986; Hu et al., 1988; Polan et al., 1988) and that oestrogen and progesterone increase macrophage functional activity in vivo (Vernon-Roberts, 1969). Recent in situ hybridization and immunohistochemical studies 

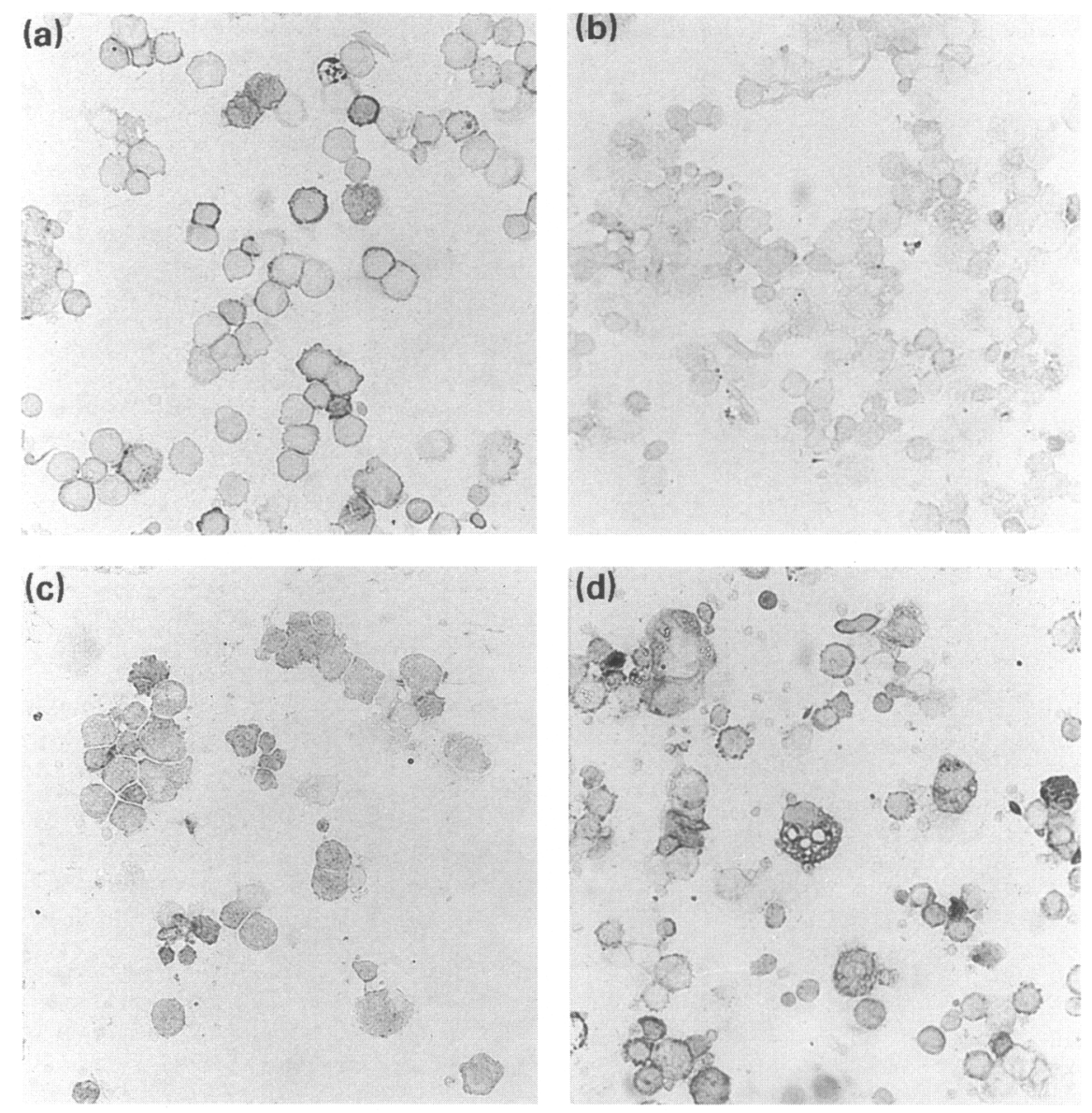

Fig. 6. Detection of interleukin 1 (IL-1), interleukin 6 (IL-6) and tumour necrosis factor alpha (TNF- $\alpha$ ) in mouse uterine cells using immunocytochemistry with specific antibodies. Cells from (a) day 3 of pregnancy stained with anti-IL-1 (scored as I+), included to show the weakest positive reaction; (b) day 4 of pregnancy stained with anti-IL-1 (scored as $4+$ ); (c) day 4 of pregnancy stained with anti-IL- 6 (scored as $3+$ ); and (d) day 4 of pregnancy stained with antiTNF- $\alpha$ (scored as $3+$ ).

localized IL-1 and TNF- $\alpha$-producing cells to the subepithelial stroma in nonpregnant mice (Takacs et al., 1988), the subepithelial stroma early in pregnancy (McMaster et al., 1992) and the peridecidual region during the peri-implantation period. Those are areas where macrophages are concentrated (De et al., 1992).

If increased cytokine production in the uterus was due solely to direct stimulation of macrophage IL-1 transcription and translation by oestrogen and progesterone (Flynn, 1986; Hu et al., 1988; Polan et al., 1988; De et al., 1992), cytokine concentrations should have been high in all tissues. There was no evidence for increased cytokine mRNA expression in the liver and previous surveys of normal animals provided no support for cyclic expression of cytokine genes in other normal tissues (Billingham, 1987; Takacs et al., 1988; Balkwill and Burke, 1989; Dinarello, 1989; Durum and Oppenheim, 1989). Those data demonstrate, but do not explain, tissue-specific increases in cytokine production in the uterus during pregnancy.

Many pathologic events involve a common cascade of tissue changes, including increased vascular permeability, vasodilation, cell proliferation, cell differentiation, cell death and fibrosis. Those inflammatory changes are mediated by factors that include pro-inflammatory cytokines (IL- 1, IL- 6 and TNF- $\alpha$ ), prostaglandins, leukotrienes, histamine, fibroblast growth factor, platelet-derived growth factor and the transforming growth factors (Billingham, 1987; Balkwill and Burke, 1989; Dinarello, 1989; Durum and Oppenheim, 1989). Each of those factors is regulated, at least in part, by IL-1 (Dinarello, 1989; Di Giovine and Duff, 1990). Two of the IL-I-induced factors, prostaglandins and histamine, are essential components in the preparation of the uterus for implantation (Shelesnyak, 1955; Kennedy, 1977; Malathy et al., 1986). Although blastocyst implantation is a normal physiological event and the intrauterine changes that surround implantation are neither pathologic nor resemble acute or chronic inflammation, the possible role of IL- 1 and factors induced by IL- $I$ in preparation of the uterus for implantation merits further investigation.

We would like to thank G. K. Andrews for extensive help and advice. A cDNA clone for murine IL- $1 \alpha$ was generously provided by Hoffman-La Roche, Inc. A cDNA clone for murine IL-1 $\beta$ was generously provided by J. Huang (E.I.duPont de Nemours \& Co.). A cDNA clone for murine IL-6 (molL-6) was generously provided by DNAX Research Institute of Molecular and Cellular Biology, Palo Alto, CA. A 
CDNA clone for TNF- $\alpha$ was generously provided by Genentech, Inc., San Francisco, CA. IL- 6 bioassays were generously performed by $M$. Kluger, University of Michigan, Ann Arbor, MI. The research was supported by NIH grant HD17678 and by Wesley Foundation grant T8811008.

\section{References}

Andrews GK, Lehman LD, Huet YM and Dey SK (1987) Metalothionein gene regulation in the preimplantation rabbit blastocyst Development 100 463-469

Aviv $H$ and Leder $P$ (1972) Purification of biologically active globin messenger RNA by chromatography on oligothymidylic acid cellulose Proceedings of the National Academy of Sciences USA 69 1409-1416

Balkwill FR and Burke F (1989) The cytokine network Immunology Today 10 299-304

Billingham MEJ (1987) Cytokines as inflammatory mediators British Medical Bulletin 43 350-370

Brigstock DR, Heap RB and Brown KD (1989) Polypeptide growth factors in uterine tissues and secretions Jourmal of Reproduction and Fertility 85 747-758

Croze F, Kennedy TG, Schroedter IC, Friesen HG and Murphy LJ (1990) Expression of insulin-like growth factor-I and insulin-like growth factorbinding protein- $\mathrm{I}$ in the rat uterus during decidualization Endocrinology $\mathbf{1 2 7}$ 1995-2000

De M, Choudhuri R and Wood GW (1991) Determination of the number and distribution of macrophages, lymphocytes and granulocytes in the mouse uterus from mating through implantation Joumal of Leukocyte Biology 50 $252-262$

De M, Sanford TR and Wood GW (1992) Interleukin-1, interleukin- 6 and tumor necrosis factor alpha are produced in the mouse uterus during the estrous cycle and are induced by estrogen and progesterone Developmental Biology $151297-305$

DiAugustine RP, Petrusz P, Bell GI, Brown CF, Korach KS, McLachlan JA and Teng CT (1988) Influence of estrogens on mouse uterine epidermal growth factor precursor protein and messenger ribonucleic acid Endocrinology 122 $2355-2363$

di Giovine FS and Duff GW (1990) Interleukin I: the first interleukin Immunology Today 11 13-20

Dinarello CA (1989) Interleukin 1 and its biologically related cytokines Advances in Immunology 44 153-205

Durum S and Oppenheim JJ (1989) Macrophage-derived mediators: interleukin 1 , tumor necrosis factor, interleukin 6 , interferon and related cytokines. In Fundamental Immunology pp 639-661 Ed. WE Paul. Raven Press, New York

Flynn A (1986) Expression of la and the production of interleukin 1 by peritoneal exudate macrophages activated in vivo by steroids Life Science $\mathbf{3 8}$ $2455-2460$

Han JH, Stratova C and Rutter WJ (1987) Isolation of full-length putative rat lysophospholipase cDNA using improved methods for mRNA isolation and cDNA cloning Biochemistry 26 1617-1624

Hu SK, Mitcho YL and Rath NC (1988) Effect of estradiol on interleukin I synthesis by macrophages International Journal of Immunopharmacology 10 247-252

Huang JJ, Newton RC, Rutledge J, Horuk R, Matthew JB, Covington M and Lin $Y$ (1988) Characterization of murine IL-1 $\beta$ : isolation, expression, and purification Journal of Immunology 140 3838-3843
Huet-Hudson YM, Chakreborty C, De SK, Suzuki Y, Andrews GK and Dey SK (1990) Estrogen regulates the synthesis of epidermal growth factor in mouse uterine epithelial cells Molecular Endocrinology 4 510-523

Kennedy TG (1977) Production of leukotrienes and prostaglandins in the rat uterus during the periimplantation period Biology of Reproduction 16 286-291

Larrick JW (1989) Native interleukin 1 inhibitors Immunology Today 10 61-66

LeMay LG, Vander AJ and Kluger MJ (1990) Role of interleukin 6 in fever in rats American Joumal of Physiology 258 R798-R803

Lobel BL, Levy E and Shelesnyak MC (1967) Studies on the mechanism of nidation. XXXIV. Dynamics of cellular interactions during progestation and implantation in the rat. Part I, progestation Acta Endocrinologica 55 7-63

Lomedico PT, Gubler U, Hellman CD, Dukovich M, Giri JG, Pan YCE, Collier K, Seminow R, Chua AO and Mizel SB (1984) Cloning and expression of murine interleukin-I $\alpha$ cDNA in Escherichia coli Nature 312 458-462

McMaster MT, Newton RC, Dey SK and Andrews GK (1992) Activation and distribution of inflammatory cells in the mouse uterus during the preimplantation period Journal of Immunology 148 1699-1705

Malathy PV, Cheng HC and Dey SK (1986) Evidence for a role for prostaglandins in the initiation of blastocyst implantation in the rat Prostaglandins 32 605-615

Melton DA, Krieg PA, Rebagliati MR, Maniatis T, Zinn K and Green MR (1984) Efficient in vivo synthesis of biologically active RNA and RNA hybridization probes from plasmids containing a bacteriophage SP6 promoter Nucleic Acids Research 12 7035-7056

Mosmann T (1983) Rapid colorimetric assay for cellular growth and survival application to proliferation and cytotoxicity assays Journal of Immunological Methods 65 55-63

Murphy LJ, Murphy LC and Friesen HG (1988) Estrogen induces insulin-like growth factor expression in the rat uterus Molecular Endocrinology $1445-450$

Nelson KG, Takahashi T, Bossert NL, Walmer DK and McLachlan JA (1991) Epidermal growth factor replaces estrogen in the stimulation of female genital-tract growth and differentiation Proceedings of the National Academy of Sciences USA 88 21-25

Polan ML, Daniele A and Kuo A (1988) Gonadal steroids modulate human monocyte interleukin-1 (IL-1) activity Fertility and Sterility 49 964-968

Psychoyos A (1973) Endocrine control of egg implantation. In Handbook of Physiology - Endocrinology II, Section 7, vol II, pp 187-215 Eds RO Greep, EB Astwood and SR Geiger. American Physiological Society, Washington

Sanford T, De M and Wood GW (1992) Expression of colony stimulating factor and inflammatory cytokines in the uterus of CD1 mice during days 1 to 3 of pregnancy Journal of Reproduction and Fertility 94 213-220

Shelesnyak MC (1955) Some experimental studies on the mechanism of ova-implantation in the rat Recent Progress in Hormone Research 13 269-322

Short RV (1984) Oestrous and menstrual cycles. In Reproduction in Mammals; Hormonal Control of Reproduction, Book 3, pp 115-152 Eds CR Austin and RV Short. Cambridge University Press, New York

Takacs L, Kovacs EJ, Smith MR, Young HA and Durum SK (1988) Detection of IL-1 alpha and IL-1 beta gene expression by in situ hybridization: tissue localization of IL-1 mRNA in the normal C57BL/6 mouse Journal of Immunology 141 3081-3095

Vernon-Roberts B (1969) The effects of steroid hormones on macrophage activity International Reviews in Cyfology 25 131-159

Wood GW, Kamel S and Smith K (1988) Immunoregulation and prostaglandin production by mechanically-derived and enzyme-derived murine decidual cells Journal of Reproductive Immunology 13 235-248

Yoshinaga K, Hawkins RA and Strocker JF (1969) Estrogen secretion by the rat ovary in vivo during the estrous cycle and pregnancy Endocrinology 85 103-112 